\title{
THE NEW PERSONAL PROPERTY SECURITY REGIMES -- HAVE WE GONE TOO FAR?
}

\section{JACOB S. ZIEGEL}

The following is an excerpt from the Alberta Law Review's new book An Introduction to the Personal Property Security Act of Alberta. Professor Ziegel, who has been involved with PPSA legislation since its introduction in Canada in the 1970's, considers the philosophical underpinnings of this new wave of creditor-debtor regulations. He is concerned that the benefit to the secured creditor may be gained at the expense of unsecured parties, and suggests further fine tuning may be required to better balance the respective interests of secured and unsecured creditors.
Le texte suivant est extrait de l'ouvrage publié par l'Alberta Law Review et intitulé An Introduction to the Personal Property Security Act of Alberta. Le professeur Ziegel, qui a participé à la législation de la PPSA au cours des années soixante-dix examine quels sont les fondements philosophiques des règlements régissant la relation créancier-débiteur. ll est préoccupé par le fait que l'avantage obtenu par le créancier garanti pourrait être obtenu aux dépens du créancier chirographaire et il suggère que l'on procède à d'autres améliorations pour équilibrer les intérêts respectifs des créditeurs garantis et chirographaires.

\section{TABLE OF CONTENTS}

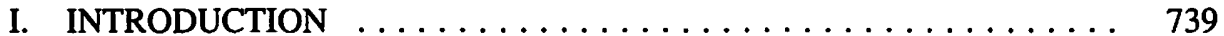

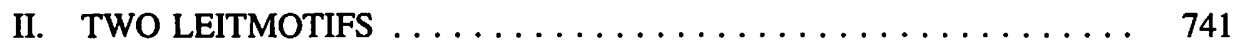

III. WINNERS AND LOSERS IN BANKRUPTCY . . . . . . . . . . . . 744

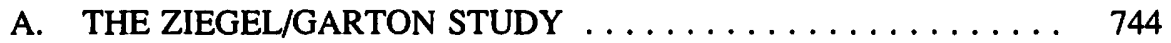

IV. JUSTIFICATION FOR SECURED CREDITORS'

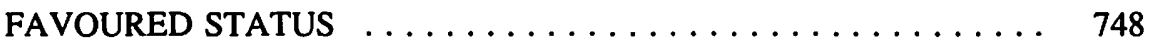

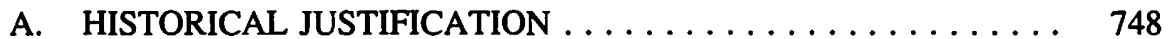

B. ECONOMIC JUSTIFICATION . . . . . . . . . . . . 750

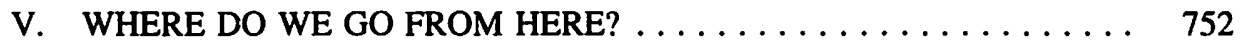

A. HELPING VULNERABLE CREDITORS . . . . . . . . . . . 752

1. Unpaid Wage Earners . . . . . . . . . . . . . . . 752

2. Consumber Claims . . . . . . . . . . . . . . . . 753

3. Trade Creditors . . . . . . . . . . . . . . . . . 754

4. The 10 Per Cent Solution .................. 754

5. Governmental Claims ................... 756

6. Enforcement of the Security Interest $\ldots \ldots \ldots \ldots 757$

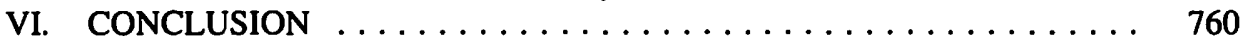

\section{INTRODUCTION}

When the Alberta Personal Property Security Act comes into force on October 1, 1990, the Province will become the sixth jurisdiction in Canada with an operative Article 9 type

Professor of Law, University of Toronto. CJacob S. Ziegel, 1990. This paper is an expanded and much revised version of a luncheon address given by the author at a Continuing Education Conference on the Ontario Personal Property Security Act, 1989, held in Toronto on March 28, 1990. 
chattel security law.' As one who has worked actively for many years to promote the adoption of modern personal property security legislations in Canada, ${ }^{2}$ I welcome warmly Alberta's accession to the club, just as I welcome British Columbia's almost simultaneous accession.

Unhappily, these and other chattel security developments are not without their difficulties. Three problems are particularly troubling. First, none of the Maritime provinces has so far adopted a Personal Property Security Act although several of the provinces have recently shown renewed signs of interest to adopt such legislation ${ }^{3}$ Second, and more disturbingly, there is no true uniformity among the Acts presently in force. For the most part, the Alberta and British Columbia Acts are (or were) identical ${ }^{4}$ and the Saskatchewan and Manitoba Acts may fall into line when these Provinces introduce their anticipated revising legislation. Nevertheless, even allowing for this consummation, there will remain substantial differences, and in one respect a basic difference, ${ }^{5}$ between the new Ontario Act and the other Acts. A third problem is that, despite repeated urging to do so, the federal government has so far shown little interest to update its own considerable body of chattel security legislation, most noticeably the Section 178 provisions in the Bank Act, to bring it into harmony with the provincial Acts.

I have written extensively elsewhere about all three problems, as have others, and I will not bore the reader by singing the same song again. A fourth issue, however, has received very little attention so far in Canada and it forms the main theme of this paper. It has taken so much time and effort to persuade the provinces to introduce the initial Personal Property Security legislation, and then to revise it where necessary, that few of us were inclined to worry whether the new Acts struck the right balance between secured and unsecured creditors. If we had addressed our minds to the question, perhaps the answers would still have been the same. We were no doubt much influenced by the fact that Article 9 had been successfully adopted by 49 state legislatures and the District of Columbia in the United States, thus giving it a powerful cachet of respectability. However, the philosophical and economic underpinnings of Article 9 are attracting an increasing volume of critical attention by legal academics in the U.S. It is time that Canadian lawyers began to do the same about the Canadian versions of Article 9.

This assumes that the British Columbia Act, S.B.C. 1989, c. 36 as am., is proclaimed, as expected, before October 1, 1990.

The writer served inter alia as chairman of the Committee on a Uniform Personal Property Security Act of the Canadian Bar Association that drafted the Uniform Personal Property Security Act 1970, and as a chairman of the Joint Committee of the Canadian Bar Association and the Uniform Law Conference of Canada that drafted the Uniform Personal Property Security Act 1982. All references to the Alberta Act are to S.A. 1988, c. P-4.05, and do not include the amendments introduced by the Personal Property Security Amendment Act, 1990 (Bill 18, 1990).

3.

4.

s. See Ziegel, "Personal Property Security Legislative Activity" (1989) 15 C.B.L.J. 108.

At least this was true before Alberta and British Columbia each introduced their amending legislation in 1990.

Viz. with respect to the status of non-security leases. The Saskatchewan, Alberta and British Columbia scope provisions include chattel leases for more than a year, as will the revised Manitoba Act. The new Ontario Act does not. 


\section{TWO LEITMOTIFS}

When describing the common themes that pervade the Article 9 legislation, it is customary to use two buzz words: rationalization and modernization. By rationalization we mean abolishing the multiplicity of common law, equitable and statutory security devices and replacing them with the generic concept of a security agreement creating a security interest ${ }^{6}$ and governed by a common set of rules, regardless of the underlying collateral or the name attached by the parties to the agreement. The Canadian Acts do draw distinctions between some types of security agreements, but they are based on functional and not historical or conceptual considerations.

By modernization of our chattel security law we mean abandoning the cumulative baggage of obsolete rules, largely of Victorian origin, and replacing them where necessary with modern rules and facilities that accept the giving of chattel security as an integral and positive part of the modern Canadian economy. So the Act abolishes affidavits of bona fides and execution for all purposes ${ }^{7}$ and establishes a computerized central registry system with, on the whole, easy filing requirements and greatly improved searching and retrieval facilities.

Regardless of how we characterize them, the following features of the Alberta Act also greatly favour the secured party's position. ${ }^{8}$ The corporate charge provisions in the Alberta Business Corporations $A c t^{9}$ have been repealed and subsumed in the new $A c t,{ }^{10}$ the floating charge has been converted into a fixed charge unless the security agreement provides otherwise ${ }^{\prime \prime}$ (this change alone is worth its weight in gold to secured parties), and the priority status of future advances has been clarified. ${ }^{12}$ Perfection by registration is permitted for security interests in all types of collateral, ${ }^{13}$ and the financing statement may be filed at any time ${ }^{14}$ and will cover all future transactions between the parties involving the same collateral. ${ }^{15}$ Equally accommodating is the fact that the secured party can choose its own registration period. ${ }^{16}$

Though the enforcement provisions retain some important consumer oriented features of existing Alberta law, ${ }^{17}$ overall they also greatly favour the secured party. Part 5

Alberta Act, ss. 3(1), 1(pp)("security agreement") and 1(qq)("security interest").

Alberta Act, ss. 1(p)("financing statement"), 25, 43(1).

I use the Alberta Act as illustrative of the provisions in all the Canadian Acts.

S.A. 1981 , c. B-15, Pt. 7, div. 2.

Alberta Act, ss. 3(1), 77.

Alberta Act, ss. 9, 12(1).

Alberta Act, s. 35(4).

Alberta Act, s. 25.

Alberta Act, s. 43(4). The new Ontario Act, s. 45(4) is somewhat clearer on the point and, unlike the Alberta Act, also draws a distinction between consumer and non-consumer goods with respect to the time of registration.

Alberta Act, s. 43(5).

Alberta Act, s. 44(1).

Notably those continuing the sheriff's role in the seizure of collateral, except where a receiver has been appointed (s. 58(2)), and the retention of the sue or seize election for consumer purchase money security interests (ss. 47-50). 
reaffirms the secured party's right to appoint a receiver extra-judicially but it is now unencumbered by all the old learning about the time of crystallization of the floating charge. ${ }^{18}$ There is no requirement for the secured party to give prior notice before seizing the collateral on default ${ }^{19}$ and the post-seizure requirements for giving notice before the collateral is sold are quite modest. The secured party is given an explicit right to recover any deficiency after a sale ${ }^{20}$ where its security is not a purchase money security interest in consumer goods. ${ }^{21}$ If the debtor does not object or, if she does, if the court overrides the objection, the secured party may exercise a right of foreclosure ${ }^{22}$ an election not open at common law for pledges or equitable charges.

We may conclude then that the result of rationalizing and modernizing Canadian chattel security law has redounded greatly to the secured party's benefit, so much so that unsecured creditors may wonder whether Alberta's Act and all the other Acts should not be restyled the Secured Creditor's Relief Act. There is more. Provincial law alone cannot guarantee the enforceability of security; the acid test arises on the debtor's bankruptcy when the trustee in bankruptcy scrutinizes the security agreement to see whether it is foolproof. Thanks to an equally accommodating Bankruptcy $A c t,{ }^{23}$ the secured party has little to fear. If the security agreement complies with provincial law and does not amount to a voidable preference, the trustee must release the collateral to the secured party unless he is in a position to redeem it or the court exercises a sparingly exercised power to order a stay of proceedings for up to six months from the date the debt becomes payable. ${ }^{24}$ The unsecured creditors of course can lay no claim to the collateral. ${ }^{25}$

Just as important from the secured creditor's point of view is the rule, recently affirmed by the Supreme Court of Canada, ${ }^{26}$ that its claim ranks ahead in bankruptcy over the claim of a preferred creditor even when federal or provincial law has established a deemed trust over the debtor's property in favour of a governmental agency. ${ }^{27}$ Secured creditors regard the Bankruptcy Act's priority rules so favourable to their interests that they will petition a debtor into bankruptcy for the sole purpose of being able to use them! $!^{28}$

One could accept a regime that is so benign to secured creditors with equanimity if one felt confident that secured creditors paid an adequate price for their favoured status and

Alberta Act, s. 65(1).

However, Canadian courts have imposed a common law notice requirement in the case of demand payment clauses and other default situations under the post-Lister Lid. v. Dunlop Canada Lid. burgeoning case law.

Alberta Act, s. 61(4).

Alberta Act, s. 87.

Alberta Act, s. 62.

R.S.C. 1985 , c. B-3.

Ibid. s. 69(2).

Ibid. s. 136(1).

British Columbia v. Henfrey Samson Belair Lid. (1989), 59 D.L.R. (4th) 726.

The case law is long and complex and continues unabated. For an excellent analysis see Kenneth C. Morlock, "Priorities Outside the PPSA" in Personal Property Security Act: Update, Law Society of Upper Canada, ch. J.

See Bk. of Montreal v. Scott Road Enterprises Ltd. (1989), 57 D.L.R. (4th) 623 (B.C.C.A.). 
that the benefits to society were at least commensurate with the benefits conferred on secured creditors. Unfortunately, neither question can be answered with confidence. I will leave for later consideration the social welfare issue and speak here briefly about the price paid by secured creditors. It consists of two parts. The first half comprises the reduced interest rate, implicit or explicit, which the secured creditor is willing to accept in exchange for the security. In a competitive market this should match the reduction in risk that the secured creditor may not be paid, together with lower monitoring costs and other savings made possible by the security. This looks sufficient (and some indeed have argued that it is $)^{29}$ to justify the secured creditor's priority position.

Unfortunately, it overlooks the fact that the benefit to the debtor of obtaining a lower interest rate will be exactly offset by the higher rate which the debtor will have to pay its unsecured creditors to compensate them for the increased risk and higher monitoring and other costs which they will incur, assuming they are perfectly informed and in a position to bargain effectively. ${ }^{30}$ So it seems that neither the debtor nor the dchtor's unsecured creditors are better off because of the debtor's ability to give security. This conclusion is so disturbing, and so counterintuitive to the way most of us think about the role of secured credit, that it will be further analyzed later in this paper.

The second half of the price paid by the secured creditor has fewer theoretical connotations and is premised on society's acceptance of the validity and utility of chattel security. It consists of the secured party being required to reduce the security agreement to writing, ${ }^{31}$ to perfect and maintain the perfection of its security interest in accordance with the applicable legislation ${ }^{32}$ and, if the collateral is seized in the event of the debtor's default, to follow the notice and other basically debtor oriented requirements in Part 5 of the Alberta Act.

For the most part, these requirements are so easily and relatively cheap to comply with $^{33}$ that unsecured creditors may think it absurd that the distinction between secured and unsecured creditors should rest on such tenuous foundations. It seems clear then that the new provincial legislation raises basic questions about the role of secured credit and the justification for treating it so favourably. Before addressing myself to these questions,

29.

See for example, Goode, "Is the Law Too Favourable to Secured Creditors?" (1983-84) 8 C.B.L.J. 53 at 57 ("bargain element widely accepted as a proper ground for giving the secured creditor priority").

30.

Schwartz, "Security Interests and Bankruptcy Priorities: A Review of Current Theories" (1981) 10 J. Legal Studies 1 at 7.

Alberta Act, s. 10.

Ibid. Parts 3 and 4.

The PPS jurisprudence to date indicates that secured parties experience the most difficulties in complying accurately with the description requirements for financing statements. This entails serious consequences if a court concludes that the error or omission "is seriously misleading". Alberta Act, s. 43(6). There has been much discussion about the role of the registry system and the appropriateness of an objective misleadingness test for the consequences of perfection errors. However, neither issue affects the fundamental question whether the PPS legislation is too favourable to secured creditors. 
it may be helpful to look a little more closely at the practical consequences of the priority enjoyed by secured claims.

\section{WINNERS AND LOSERS IN BANKRUPTCY}

Unhappily, bankruptcy is big business in Canada. For example, in 1987 there were 7,659 business bankruptcies involving $\$ 520,925$ million in assets and $\$ 1,781,238$ million in liabilities. The total deficiency between assets and liabilities amounted to an impressive $\$ 1,260,312,824 .^{34}$ These figures do not tell the whole story, first, because they do not include the large number of businesses that are place in receivership each year by secured parties outside the bankruptcy system and, second, because the figures for assets and liabilities are based on the debtor's own assessments at the time of bankruptcy. The realizations are invariably much smaller and the net deficiencies correspondingly much larger. In any event, whatever the complete figures, it is clear that unsecured creditors have reason to be concerned about how they will fare if their debtors become insolvent.

\section{A. THE ZIEGEL/GARTON STUDY}

The federal government does not publish statistics showing the results of bankruptcies and how the net proceeds of disposition of assets are distributed among the different classes of creditors. With a view to bridging this gap, the author and Billy Garton, a former student of his, conducted a survey of their own in 1988. We examined in depth 95 "pure" business bankruptcy files chosen at random from business bankruptcies that occurred in Metropolitan Toronto over a five year period. Table 1 shows the overall results of our enquiry.

As will be seen, the total liabilities of the 95 estates amounted to $\$ 28$ million but the net value of estates available for distribution only came to $\$ 5.7$ million. Total claims of secured creditors amounted to $\$ 7.85 \mathrm{~m}$ and secured creditors had the highest -but still not very impressive - rate of recovery among all creditors: $43 \%$. The claims of all preferred creditors amounted to $\$ 2.7$ million or $15.4 \%$ of total liabilities. Note carefully however that the costs of adminstration by themselves came to just over $\$ 1$ million, or $38.25 \%$ of the amount of all preferred claims. Trustees in bankruptcy enjoyed a $99 \%$ recovery in respect of their fees and expenses; all other preferred claimants only recovered $\$ 300,000$ or $17.8 \%$ of their total claims. Unsecured creditors had total claims of $\$ 17.3$ million, or $62 \%$ of all admitted claims, but only recovered, on average, $5 \%$ of their claims.

Assuming these figures are generally representative of the result of business bankruptcies (as I have been told they are), they show several things. First, predictably, 


\section{TABLE 1}

TOTAL CLAIMS

95 "PURE" BUSINESS BANKRUPTCY FLES*

\begin{tabular}{|c|c|c|c|c|c|c|c|}
\hline Claimant & $\begin{array}{l}\text { \# of } \\
\text { claims }\end{array}$ & $\begin{array}{l}\text { \% of total } \\
\text { \# claims }\end{array}$ & $\begin{array}{c}\text { claimed } \\
\$\end{array}$ & $\begin{array}{c}\% \text { of total } \$ \\
\text { claimed }\end{array}$ & $\begin{array}{l}\text { div or } \\
\$ \text { real. }\end{array}$ & $\begin{array}{c}\text { \% of total } \\
\text { div. or } \\
\text { real. }\end{array}$ & $\begin{array}{c}\text { recovery } \\
\%\end{array}$ \\
\hline secured & 140 & 2.9 & $7,856,442$ & 28.1 & $3,425,731$ & 60.2 & 43 \\
\hline preferred & 735 & 15.4 & $2,761,305$ & 9.9 & $1,355,594$ & 23.8 & 49 \\
\hline ord. unsec* & 3907 & 81.7 & $17,361.508$ & 62.0 & 911.979 & 16.0 & 5 \\
\hline Total & 4782 & 100 & $27,979,255$ & 100 & $5,693,304$ & 100 & 20 \\
\hline
\end{tabular}

*excluding deemed deficiency claims of secured creditors

secured creditors fare significantly better in bankruptcy than do preferred or ordinary creditors. Second, if costs of administration are subtracted, the other types of preferred claims only represent about $10 \%$ of all claims - a surprisingly low figure given the volume of litigation in the reports involving Crown liens, although there is probably a good explanation for it. Finally, these figures dispel the widely held belief that ordinary creditors would be much better off if Crown liens were denied preferred status in bankruptcy. The answer is that the improvement would be negligible. Ordinary creditors at best would recover $7 \%$ instead of $5 \%$ of their average claim.

Table 2 shows the distribution of secured claims. As one would expect, the chartered banks lead the group with $50.9 \%$ of all secured claims and an average claim of $\$ 86,879$. Suppliers of goods rank second with $25.3 \%$ of all secured claims and an average claim of $\$ 43,205$. This shows that the ability to take security is important for some types of suppliers, usually those selling capital equipment on credit. Other financial institutions come third, but well behind the banks and suppliers of goods. Very significant is the low ranking of suppliers of services as secured creditors. Their claims only amount to $0.3 \%$ in value of the claims of all secured creditors. This probably reflects the fact that it is not easy, or usual, for such creditors to obtain security for their claims. 
TABLE 2

95 "PURE" BUSINESS BANKRUPTCY FILES

ALL. SECURED CLAIMS

\begin{tabular}{|c|c|c|c|c|c|c|c|c|c|c|c|}
\hline \multirow{2}{*}{$\begin{array}{l}\text { Claimant } \\
\text { Type }\end{array}$} & \multirow{2}{*}{$\begin{array}{l}\text { \# of } \\
\text { clms }\end{array}$} & \multicolumn{2}{|c|}{ \%o of \# claims } & \multirow{2}{*}{$\begin{array}{l}\text { claimed } \\
\text { s }\end{array}$} & \multirow{2}{*}{$\begin{array}{l}\text { Avg. } \\
\text { claim } \\
S\end{array}$} & \multicolumn{2}{|c|}{ \% of S claimed } & \multirow{2}{*}{$\begin{array}{l}\text { div. or } \\
\text { S real. }\end{array}$} & \multicolumn{2}{|c|}{$\%$ of $S$ real. } & \multirow{2}{*}{$\begin{array}{l}\text { recov- } \\
\text { ery } \\
\%\end{array}$} \\
\hline & & $\begin{array}{l}\text { sub- } \\
\text { tot }\end{array}$ & tot & & & $\begin{array}{l}\text { sub- } \\
\text { tot }\end{array}$ & tot & & $\begin{array}{l}\text { sub- } \\
\text { tot }\end{array}$ & 101 & \\
\hline $\begin{array}{l}\text { 1-1 } \\
\text { Bants }\end{array}$ & 46 & 32.9 & 1.0 & $3,996,434$ & 86,879 & 50.9 & 14.3 & $1.797,805$ & 52.5 & 31.6 & 44 \\
\hline $\begin{array}{l}1.2 \text { oth } \\
\text { fin. inst }\end{array}$ & 30 & 21.4 & 0.6 & 1.268 .264 & 42,275 & 16.1 & 4.5 & 469,189 & 13.7 & 8.2 & 36 \\
\hline $\begin{array}{l}\text { 1-3 suppl. } \\
\text { of goods }\end{array}$ & 46 & 32.9 & 1.0 & $1,987,416$ & 43,205 & 25.3 & 7.1 & 824.972 & 24.1 & 14.5 & 41 \\
\hline $\begin{array}{l}1.4 \\
\text { services }\end{array}$ & 12 & 8.5 & 0.2 & 20,833 & 1.736 & 0.3 & 0.1 & 803 & 0.0 & 0.0 & 3 \\
\hline $\begin{array}{l}1-7 \\
\text { others }\end{array}$ & 6 & 4.3 & 0.1 & 583,495 & 97,249 & 7.4 & 2.1 & 332.962 & 9.7 & 5.8 & 57 \\
\hline sub-tot & 140 & 100 & 2.9 & 7.856 .442 & 56,117 & 100 & 28.1 & $3,425,731$ & 100 & 60.1 & 43 \\
\hline
\end{tabular}

Finally, Table 3 shows the distribution of unsecured claims. Several features should be noted here. There are many more types of unsecured creditors than there are of secured creditors. The principal groups of unsecured claimants are not financial institutions but, in order of importance, suppliers of goods (39.2\%), suppliers of services $(23.6 \%)$ and private lenders $(20.0 \%){ }^{35}$ Also significant is the fact that the value of the claims of unsecured suppliers ( $\$ 6.79$ million) is more than three times the value of the claims of secured suppliers ( $\$ 1.98$ million). This confirms the common belief that ordinary trade creditors do not hold security in respect of their claims.

35. The private lenders were primarily principals of the business or persons related to the principals. 
TABLE 3

ORDINARY UNSECURED CLAIMS

(excluding deemed deficiency claims of secured creditors)

95 "PURE" BUSINESS BANKRUPTCY FILES

\begin{tabular}{|c|c|c|c|c|c|c|c|c|c|c|c|}
\hline \multirow[t]{2}{*}{ Claimant } & \multirow{2}{*}{$\begin{array}{l}\text { \# of } \\
\text { clms }\end{array}$} & \multicolumn{2}{|c|}{$\%$ of \# claims } & \multirow{2}{*}{$\begin{array}{l}\text { claimed } \\
\$\end{array}$} & \multirow{2}{*}{$\begin{array}{c}\text { Avg. } \\
\text { claim } \\
\$\end{array}$} & \multicolumn{2}{|c|}{$\phi_{0}$ of $\$$ claimed } & \multirow{2}{*}{$\begin{array}{l}\text { div. or } \\
\text { Sreal. }\end{array}$} & \multicolumn{2}{|c|}{$\%$ of \$ real. } & \multirow{2}{*}{$\begin{array}{c}\text { recov- } \\
\text { ery } \\
\%\end{array}$} \\
\hline & & $\begin{array}{l}\text { sub. } \\
\text { tot }\end{array}$ & tot & & & $\begin{array}{l}\text { sub- } \\
\text { tot }\end{array}$ & tot & & $\begin{array}{l}\text { sub- } \\
\text { tot }\end{array}$ & tot & \\
\hline $\begin{array}{l}\text { 3-1 } \\
\text { Banks }\end{array}$ & 79 & 2.0 & 1.6 & $1,501,631$ & 19,008 & 8.6 & 5.4 & 8,902 & 1.0 & 0.1 & 1 \\
\hline $\begin{array}{l}\text { 3-2 oth } \\
\text { fin. inst. }\end{array}$ & 55 & 1.4 & 1.1 & 748.936 & 13,617 & 4.3 & 2.7 & 24,308 & 2.7 & 0.4 & 3 \\
\hline $\begin{array}{l}\text { 3-3 suppl. } \\
\text { of goods }\end{array}$ & 1,803 & 46.2 & 37.7 & $6,798,671$ & 3,771 & 39.2 & 24.3 & 667,267 & 73.2 & 11.7 & 10 \\
\hline $\begin{array}{l}3-4 \\
\text { services }\end{array}$ & 1,047 & 26.8 & 21.9 & $4,096,940$ & 3,913 & 23.6 & 14.6 & 105,831 & 11.6 & 1.9 & 3 \\
\hline $\begin{array}{l}3.6 \\
\text { util. }\end{array}$ & 144 & 3.7 & 3.0 & 131,835 & 916 & 0.8 & 0.5 & 4,602 & 0.5 & 0.1 & 3 \\
\hline $\begin{array}{l}3.7 \\
\text { wages }\end{array}$ & 65 & 1.7 & 1.3 & 106,672 & 1,641 & 0.6 & 0.4 & 7,191 & 0.8 & 0.1 & 7 \\
\hline $\begin{array}{l}3-8 \\
\text { indiv. } \\
\text { lenders }\end{array}$ & 343 & 8.8 & 7.2 & $3,468,943$ & 10,114 & 20.0 & 12.4 & 75,260 & 8.2 & 1.3 & 2 \\
\hline $\begin{array}{l}3-9 \\
\text { mun. } \\
\text { claims }\end{array}$ & 76 & 1.9 & 1.6 & 121,201 & 1,595 & 0.7 & 0.4 & 11,671 & 1.3 & 0.2 & 10 \\
\hline $\begin{array}{l}3-10 \\
\text { other }\end{array}$ & 267 & 6.8 & 5.6 & 287,971 & 1,079 & 1.7 & 1.0 & 4,591 & 0.6 & 0.1 & 2 \\
\hline $\begin{array}{l}3 \cdot 11 \\
\text { rent }\end{array}$ & 27 & 0.7 & 0.6 & 98,708 & 3,656 & 0.5 & 0.4 & 2,356 & 0.2 & 0.0 & 2 \\
\hline sub-tot & 3,907 & 100 & 81.7 & $17,361,508$ & 4,444 & 100 & 62.1 & 991,979 & 100 & 16.0 & 5 \\
\hline
\end{tabular}

\section{JUSTIFICATION FOR SECURED CREDITORS' FAVOURED STATUS}

The above figures show that unsecured creditors have reason to be concerned about their low rates of recovery in bankruptcy and that if they want to recover more than 5 
cents on the dollar they had better obtain security themselves if they can get it. The alternative is for them to ensure that their overall rate of loss from credit extended to all customers does not impair the solvency and profitability of their own business. It does not however follow that secured credit is bad because it results in a lower rate of recovery by unsecured creditors. To make out such a case one would have to show that the cost of secured credit exceeds its benefits. What then is the justification for allowing one group of creditors to enjoy priority over another?

\section{A. HISTORICAL JUSTIFICATION}

The first justification is historical. All legal systems, however primitive, recognize the giving of security to some extent. It can also be shown that the evolution and complexity of a country's chattel security system varies in direct proportion with its economic and industrial development. Certainly this is true of the history of secured transactions in the common law world. Prior to the industrial revolution of the 19th century, chattel security devices played a very modest role in the United Kingdom. With the arrival of the industrial revolution the need for all forms of credit grew rapidly, and with it the search by creditors for better and more flexible forms of consensual security.

Common law doctrines, particularly on the equity side, quickly adapted themselves to the new economic environment and, on the whole, showed themselves very sympathetic to it. The common law courts recognized chattel mortgages on existing goods and such familiar title retention devices by suppliers of durables as conditional sales ${ }^{36}$ and hirepurchase agreements. ${ }^{37}$ The familiar pledge of goods was quickly extended to the pledging of documentary intangibles such as instruments, securities, and documents of title. Equity pushed out the frontiers where the common law hesitated to go as by recognizing the validity of mortgages on after-acquired goods ${ }^{38}$ and present and future receivables $^{39}$ and, above all, by accepting the all encompassing floating charge over the present and future non-fixed assets of an undertaking. There was some initial hostility towards non-possessory security interests on the part of the British Parliament in the form of Bills of Sale legislation, applicable to chattel mortgages given by individuals and unincorporated businesses, but the mood did not long endure. Conditional sale and hirepurchase agreements are still not required to be registered in England, and fixed and floating charges and similar encumbrances by companies are only subject to the modest perfection requirements imposed by successive Companies Acts.

The Canadian history has substantially tracked British developments with two exceptions. First, the Canadian common law provinces were quicker, and more consistent, than the British Parliament in imposing registration requirements for non-possessory security devices. Second, there was a greater and earlier disposition to provide some protection for defaulting debtors although the degree of protection varied widely among the provinces. The fact remains that even before the introduction of Ontario's first 
Personal Property Security Act in $1967^{40}$ a determined creditor had little difficulty tying up all of a debtor's assets and, in the case of banking loans, frequently did so in the form of a fixed and floating charge. The difference lay in the fact that it was more expensive and more time consuming than it is now, and more liable to be upset on the grounds of non-compliance with highly technical perfection requirements. Non-centralized registration offices and manually maintained records also made it more difficult to discover existing encumbrances.

The pre-Article 9 history of chattel security law in the U.S. differed significantly in detail, ${ }^{41}$ and in important respects in substance, from the British and Canadian histories. On the whole, American courts were less benevolent to the claims of secured creditors than were British and Canadian courts, and state legislatures were more hesitant to sweep away common law restrictions. Nevertheless, according to Grant Gilmore, from about the turn of the present century, the tide began to turn perceptibly in the secured creditors' favour and, with some troubling exceptions, maintained this direction until work on Article 9 was begun in the early 1940s. This led him to conclude that Article 9 is not so much "a new start or fresh approach as it is a reflection of work long since accomplished." ${ }^{142}$ In my view, the same observation can be made with even greater justification about the state of Canadian law in the late 1950s when the Catzman Committee in Ontario started work on the original Ontario Personal Property Security Act. However, I think it goes too far to claim that the various provincial Personal Property Security Acts were merely dotting the i's and crossing the t's on a manuscript that was complete in all other aspects.

I appreciate that legal history, like any other narrative, has no prescriptive force and that proving that personal property security legislation is the culminating event of a hundred years of legal evolution does not prove the social utility of secured credit. It may be that secured creditors are more effective lobbyists than less influential unsecured creditors or that courts or legislatures wrongly assumed the beneficial effects of secured credit. Nevertheless, one should not lightly dismiss a century of legal experience that has become such an integral part of our commercial legal culture.

\section{B. ECONOMIC JUSTIFICATIONS}

It will seem curious to future historians that until the emergency of the modern law and economics movement lawyers never thought seriously about the economic justification for secured credit. It seems to have been assumed that since commercial credit had long been recognized as economically beneficial, then secured credit must be no less so, especially if the lender was only willing to make a loan on such terms. This reasoning, however, overlooked an important difference: secured credit reduces the bundle of assets available to satisfy the claims of unsecured creditors and treats the secured creditor

40.

S.O. 1967 c. 73

41. The details will be found in Grant Gilmore's classic text, Security Interests in Personal Property (1965), vol. 1, ch. 1-8.

42. 
preferentially when it counts most - when the debtor, for whatever reason, has become insolvent. The addition of another unsecured creditor on the other hand leaves the bundle of assets intact (or even adds to it if the loan is used to purchase additional assets) and does not disturb the principle of the equality of treatment of creditors.

Professor Goode has suggested ${ }^{43}$ that the justification for the priority of the secured creditor has traditionally rested on three principles: bargain, value and notice. ${ }^{44}$ According to this reasoning, the secured creditor is entitled to look to the debtor's assets in preference to other creditors because he bargained for that right. If, he argues, another creditor chooses to lend money or supply goods unsecured, that is his affair, but he has no right to complain of being subordinated.

Professor Goode's views were obviously much influenced by a leading article by Professors Jackson and Kronman. ${ }^{45}$ These authors support the bargain theory of security but also advance a more sophisticated version of it. If security were abolished, they argue ${ }^{46}$ lenders anxious to overcome the restriction would have to engage in expensive bargaining with the debtor's other creditors to secure priority over their claims. To avoid these high costs, the creditors "authorize" the debtor to bind them by giving security to the lender.

Both aspects of the bargain theory have their weaknesses; both are predicated on informed and freely consenting creditors who readily acquiesce in the debtor giving priority to one of their number even though they may derive no benefit from it. It must be obvious however that the assumption is partly fictitious and that there is a substantial group of consensual and non-consensual creditors - trade creditors, consumers, employees, tort claimants and a long list of government agencies - who have no option but to extend credit to the debtor, and who cannot offset the risk of not being paid by charging a higher price.

Professor Alan Schwartz rejects the bargain theory. ${ }^{47}$ In a seminal article, which has provoked much discussion, he argues ${ }^{48}$ that the principal justification for a distribution scheme "that seemingly advantages the sophisticated and relatively affluent, who often take security, at the expense of the relatively poor and unsophisticated, who often do not, is that the institution of secured debt is efficient." By efficienct he apparently means that the debtor and/or the debtor's unsecured creditors as a whole must be made better off as a result of the giving of security. Prima facie, in his view, such efficiency results do not follow because the secured party charges a lower rate of interest than he would if security

43. Supra, note 27 at 57.

44. "Value" here refers to new value. "Notice" means actual notice by unsecured creditors that security has been given or constructive notice through the secured party's possession of the collateral or through compliance with a registration requirement in a publicly accessible register.

45. Jackson \& Kronman, "Secured Financing and Priorities Among Creditors" (1979) 88 Yale L.J. 143.

46. Ibid. at 1157-58.

47. Schwartz, "Security Interests and Bankruptcy Priorities" (1981) 10 J. Leg. Stud. 1 and ibid. "The Continuing Puzzle of Secured Debt" (1984) 37 Vand. L. Rev. 1051.

48. $10 \mathrm{~J}$. Legal Studies 1 at 2, and $c f .37$ Vand. L. Rev. at 1068-69. 
were not available. It does not follow ${ }^{49}$ because if the debtor's unsecured creditors are informed, can calculate risks of default, are risk neutral and have homogeneous expectations respecting default probabilities, they will charge higher interest rates because the pool of assets available to satisfy their claims has shrunk. In other words, given an informed body of unsecured creditors, neither the debtor nor the unsecured creditors will be any better off and secured credit is a zero sum game. On the other hand, those unsecured creditors who cannot protect themselves will be made worse off.

Given his initial premise that efficiency gains must be shown to justify the secured creditor's superior position, Professor Schwartz then examines ${ }^{50}$ a variety of explanations that purport to show efficiency gains - monitoring costs, secured debt as a signal, staggering debt, risk aversion, uncertainty, and heterogeneous expectations. He finds them all unsatisfactory on one of three grounds. ${ }^{51}$ Despite his agnosticism, Professor Schwartz does not recommend ${ }^{52}$ the abolition of security since he does not exclude the possibility that further research will resolve the efficiency puzzle. He feels that further investigation is necessary to determine the classes of unsecured creditors who are adversely affected by secured credit, and the degree of their vulnerability. Once they have been established, he would give them priority over secured creditors rather than using their existence as a reason for abolishing security altogether.

A flourishing industry has since grown up among legal scholars (mainly American) seeking to answer Professor Schwartz's challenge. ${ }^{53}$ As a non-economist I am not in a position to judge whether Professor Schwartz is right in claiming ${ }^{54}$ that they have not answered the puzzle. ${ }^{55}$ It does seem surprising however that the participants in this debate implicitly accept Professor Schwartz's position that the bargain theory is not a sufficient justification for the secured creditor's priority position.

\section{WHERE DO WE GO FROM HERE?}

$10 \mathrm{~J}$. Leg. Stud. 1 at 7.

$10 \mathrm{~J}$. Leg. Stud. 1 at 9 et seq.

Viz. (1) that they predict wrongly the absence or presence of security; (2) that they fail to explain why creditors use security rather than other devices; and (3) that they fail to show that the social gains from security exceed its social costs. Ibid. at 29.

lbid. at 33 et seq.

See inter alia Buckley, "The Bankruptcy Priority Puzzle" (1986) 72 Va. L. Rev. 1393; Levmore, "Monitors and Freeriders in Commercial and Corporate Settings" (1982) 92 Yale L.J. 49; and Scott, "A Relational Theory of Secured Financing" (1986) 86 Col. L. Rev. 901. Supra, note 46 (37 Vand. L. Rev. 1051).

Professor Scott's article, supra, note 51, is one of the more readable and interesting. He argues that where a debtor wants to expand its business or exploit a new opportunity but is not large enough to have access to the capital market to raise the necessary funds, a secured lender can synergistically fulfill that role to the mutual benefit of both parties and the debtor's unsecured creditors. The lender requires security, he argues, to monitor the debtor's conduct effectively and to prevent opportunistic behaviour. Even if Professor Scott is right about the efficiency of such forms of relational financing, it would only account for a small fraction of the total volume of outstanding secured credit. 
My own hunch is that most informed unsecured creditors who are in a position to protect their own interests would accept the bargain theory of security and would not wish to roll back the clock. In any event, most of them are themselves heavy and regular users of secured credit and, in the case of suppliers of goods, often retain a security interest in the goods they sell. However, this does not end the enquiry. We must still consider the substantial number of unsecured creditors, those who are ill informed or have no option but to extend unsecured credit and are therefore disadvantaged by secured credit, and determine what should be done about them. We need also to consider whether the secured party's enforcement rights need to be more closely circumscribed, particularly with respect to the appointment of receivers, and whether our bankruptcy reorganization rules need to be revised so as to oblige secured parties to cooperate in rehabilitating insolvent creditors where a salvage operation shows reasonable prospects of success. The following non-exhaustive notes address some of these issues.

\section{A. HELPING VULNERABLE CREDITORS}

\section{Unpaid Wage Earners}

The plight of unpaid wage earners on the bankruptcy of their employer has received much legislative attention over the past 15 years since the Study Committee on Bankruptcy and Insolvency Legislation first presented its report in 1970. ${ }^{56}$ There is near unanimous agreement that wage earners need better protection than the preferred position they enjoy in s. 136(1) of the Bankruptcy Act. ${ }^{57}$ There is disagreement however whether the right solution is to give wage eamer claims priority over secured claims or whether the federal government should establish a wage earner contributory insurance fund or indemnify unpaid wage earners out of the Consolidated Revenue Fund without the benefit of insurance premiums. ${ }^{58}$ The federal government has wavered between these alternatives. The Bankruptcy Advisory Committee in its 1986 Report favoured the establishment of a contributory "wage earner" fund and this won the support of the Legislative Review Branch of Consumer and Corporate Affairs Canada later that same year. However, it is far from certain that this is the route the government will follow. If and when the promised amending legislation is introduced, it is still possible that the government will opt to make good any wage earner's losses out of the Consolidated Revenue Fund on the grounds that this will be administratively cheaper than setting up yet another welfare fund.

It seems odd that the taxpayer should be expected to absorb a claim that more properly belongs to the bankrupt's estate. The banks have argued in the past that a wage earner's

See Ziegel, "The Travails of Bill C-12" (1983-84) 8 C.B.L.J. 374.

57. Under s. 136 wage earmers rank below all secured claims, and rank fourth among preferred creditors up to a maximum of $\$ 500$ for services rendered during the 3 month period preceding the employer's bankruptcy. 
superpriority claim would endanger a creditor's security because a large employer could go bankrupt owing a large sum of money to unpaid workers. The danger seems to me exaggerated. In the Ziegel/Garton study referred to previously the preferred claims of wage earners only amount to $\$ 42,295$ and represented only $1.5 \%$ of the value of all preferred claims. Non-preferred wage claims amounted to $\$ 106,672$ or $.6 \%$ of all unsecured claims. It seems therefore that secured creditors would not be running large risks in being subordinated to wage earner claims. Admittedly, however one cannot be dogmatic. ${ }^{59}$ A possible compromise would be to limit secured parties' exposure to a small percentage of the realized value of their security.

\section{Consumer Claims}

Consumer claims in bankruptcy arise in a variety of contexts. The ones that appear to have surfaced most frequently in recent years involve consumers who have prepaid for goods that were never delivered by the retailer. ${ }^{60}$ It is difficult to argue that the consumer should not have trusted the retailer or should have made credit enquiries before making the prepayment. The British Columbia Law Reform Commission considered the problem in a recent report. ${ }^{61}$ It rejected the possibility of requiring the retailer to hold prepayments on trust as too expensive to monitor. It opted instead for a double barrelled solution. First, the buyer would be given a first lien on goods in the retailer's possession corresponding in kind to those ordered by the buyer. Second, a lien would be created in the buyer's favour on any account in a savings institution (sic) into which the seller usually deposits proceeds of sales. Predictably, secured creditors objected strenuously to both proposals and warned that credit would dry up for some retailers. The Commission was undeterred and countered with the observation that even if some tightening of credit resulted, "the public interest would be better served if a retail seller who could operate only by putting a substantial number of consumer buyers at risk never opened its door to the public." ${ }^{162}$

\section{Trade Creditors}

As previously noted (Table 3), in the Ziegel/Garton study the claims of unsecured suppliers of goods and services amount to about $\$ 10.8$ million or about $50 \%$ more than the claims held by all secured creditors $(\$ 7.85$ million). It is clear therefore that trade creditors are heavy losers in bankruptcy. This is no cause for alarm if we assume that the

Hard figures are not available for the current rate of unpaid wage eamer claims against insolvent employers. The Legislative Review Branch, op.cit., p. 2, estimated them in the range of $\$ 30-\$ 50$ million annually. This seems on the high side. The Final Report of the Commission of Inquiry into Wage Protection in Insolvency Situations (Toronto 1985) estimated them at around \$6 million annually for Ontario. Assuming the rate of claims is roughly comparable in the other Provinces, this would yield a total of at most $\$ 20$ million. These figures only reflect the magnitude of the claims for unpaid wages; the net deficiency after allowing for recoveries from the bankrupt estate and from officers and directors of the insolvent incorporation could be expected to be substantially smaller. See for example, Royal Bank of Canada v. 216200 Alberta Lid. (1987), 51 Sask. R. 147 (C.A.). Report on the Buyer's Lien: A New Consumer Remedy, L.R.C. 93, 1987. The Report is reviewed by Professor Wood in (1988) 14 C.B.L.J. 118.

Wood, ibid. at 121. 
creditors knew they were running a calculated risk and were able to provide for it. However, small trade creditors frequently are not able to protect themselves either because they do not have enough customers to be able to spread the risk around or because they are not large enough to justify hiring a special credit officer. Parliament has recognized the problem in the banking context by subordinating a bank's Section 178 security to the claims of a grower or producer of agricultural products for money owing by a manufacturer for products delivered to the manufacturer by the farmer. ${ }^{63}$ The difficulty about using this approach across the whole spectrum of trade creditors is that it would be administratively difficult and time consuming to single out those small trade creditors who are most vulnerable and truly deserving of protection. Another and perhaps more formidable objection is that a substantial accumulation of such priority claims would undermine the secured party's security and potentially convert it into an unsecured claim.

\section{The 10 per cent Solution}

It may well turn out on closer examination that the lender's fears are exaggerated or that the lender is less risk averse than the small trade creditor. These possibilities do not detract however from the secured party's general concern that his security will be eroded by a proliferation of various types of superpriorities. Those who are persuaded by this reasoning may be attracted by the Cork Committee's recommendation in the U.K. This provided $^{64}$ for the establishment of a fund equal to $10 \%$ of the net moneys otherwise payable to the chargee from realization of assets subject to the floating charge. This would be set aside and distributed pari passu among the ordinary unsecured creditors, subject to the overriding limitation that unsecured creditors would not receive a greater percentage of their debts than the holder of the floating charge. The Committee's aim was not to find a simple alternative to the cumulation of small priority claims by deserving unsecured creditors, but to assuage the general complaint of unsecured creditors that they were left empty handed in most bankruptcies.

The British government rejected the Committee's recommendation and the British Insolvency Act 1986 contains no fund provision for unsecured creditors. Could the recommendation find a fruitful outlet in Canada? There are several difficulties. First, it is difficult to see why all unsecured creditors should benefit from a $10 \%$ fund if one posits that most of them are sufficiently large and sophisticated to protect themselves without Parliament's aid. In fact, it may be argued that such creditors would receive a windfall since they will already have provided against the risk of customer insolvency in their general price structure.

The second difficulty is that the Committee's unrealistic examples ${ }^{65}$ greatly inflate the benefits unsecured creditors would derive from a $10 \%$ fund. In each case the examples assume that total unsecured claims are much smaller than the floating charge holder's claim. If we substitute the amounts appearing in the Ziegel/Garton study, then it will be

63. Bank ACt, R.S.C 1985, c. B-1, s. 178(7)(b).

64. Cork Report, paras. 1538 et seq. The summary that follows is taken from Goode, supra, note 28 at 67-68.

65. Goode, supra, note 28, Appendix at 76-78. 
seen that unsecured creditors' dividends would only increase by about one-third, from 5\% to $6.7 \%$ - hardly enough to excite any creditor! The arithmetic looks as follows:

Secured Parties' Realization

$\$ 3.4 \mathrm{~m}$

Amount derived from 10\% Fund

$\$ 340,000$

Unsecured Creditors' Claims

$\$ 17.361 \mathrm{~m}$

Dividend paid

$\$ 912,000$

Add amount from $10 \%$ fund

$\$ 340.000$

TOTAL AMOUNT available for distribution among unsecured creditors

$\$ 1,252,000$

Equivalent Dividend

$6.7 \%$

Nevertheless, the Committee's recommendation should not be dismissed out of hand. It may still serve a useful purpose if the $10 \%$ fund were restricted for distribution among small and particularly vulnerable creditors. If we assume in the above example that they represent in value $10 \%$ of all unsecured claims, the availability of a 10 per cent fund would enable small creditors to receive a dividend of $24.6 \%$ or almost five times more than before.

\section{Governmental Claims (Crown Liens)}

Contests between secured creditors and the many different types of governmental lien claims for federal and provincial taxes, workmen's compensation premiums and other welfare plans have probably generated more litigation than any other priority issue involving secured claims. ${ }^{66}$ It is easy to see why this should be so. The federal and provincial governments are in the fortunate position of being able to dictate their own priorities. Almost unfailingly, they exercise the power by declaring their claims to constitute a first lien over all the debtor's assets, regardless of any existing liens, or by deeming any taxes or premiums collected or deducted by the debtor to be held on trust for the Crown. Secured creditors cannot afford to ignore such claims; there are simply too many of them, they surface too often on the debtor's bankruptcy, and the amounts involved are often substantial. So secured creditors fight them instead and, as we have seen, with a substantial measure of success in light of the pro-secured creditor provisions in s. 136(1) of the Bankruptcy Act. ${ }^{67}$ 
Few would claim, however, that litigation is the right answer or that $\mathbf{s}$. 137(1) represents a perfect solution. Instead, since 1970, a series of studies and Parliamentary Bankruptcy Bills have put forward alternative solutions. The one consistently favoured by secured creditors and trustees in bankruptcy involves the abolition of any priority status for Crown claims. Secured creditors claim that the attempt by governments to give themselves superpriority status is both unfair and severely disruptive. It also makes it very difficult for secured creditors to know how much of the collateral or its proceeds will be available to satisfy their claims if enforcement of the security should become necessary. They also argue that it would be cheaper for governments to cover losses resulting from uncollected taxes from the Consolidated Revenue Fund than to give the claims superpriority status.

Trustees in bankruptcy endorse the last argument and also put forward two of their own. The first is that Crown claims do not deserve to rank ahead of even unsecured claims because government agencies rarely take an interest in the administration of bankrupt estates. The other reason that is often advanced is that the Crown's priority also discourages unsecured creditors from playing a role since they see such participation as ultimately only enuring for the Crown's benefit. This reasoning is not particularly persuasive since it is easy to show that eliminating all Crown claims would only modestly improve the dividend rate received by unsecured creditors. Using the Ziegel/Garton study as an example, ordinary creditors' rate of recovery would only increase from $5 \%$ to $7 \%$.

Bill $C-17$ of 1984, the most recent (and perhaps last) of the federal government's attempts to introduce a comprehensive revision of the Bankruptcy Act, contained a series of provisions dealing with crown liens ${ }^{68}$ which, on the whole, were very favourable to secured creditors. The details need not be examined here. Suffice it to say that under those proposals ${ }^{69}$ Crown claims would only have enjoyed a preferred, not a superpriority, status on claims which the debtor was required by statute to collect on behalf of the Crown and to hold separate and apart from his or her own moneys. Even then the preferred status would have been limited to an amount not exceeding the amount held by the debtor in cash or on deposit at the date of bankruptcy. Under s. 270(2), deemed trusts would only have survived if a trust had been created in fact and the moneys collected by the debtor had been kept separate and apart by the debtor. Finally, s. 270(1) contained a registration requirement for government security interests established by statute, which might have provided a workable solution to some of the priority conflicts had it been more carefully drafted. ${ }^{70}$

Leaving aside such drafting difficulties, the basic question remains: What principles should inform the distributional provisions of modern bankruptcy legislation? It is difficult to apply bargain theories, since government agencies are involuntary creditors and have no option about whether or not to extend credit to the debtor. Nor can it be said that the net social gains conferred by secured credit justify the secured creditor's priority over analyzed by Bogart in (1983-84) 8 C.B.L.J. 129. 
governmental claims since, as we have seen, the efficiency claims remain controversial. Even if they were accepted as valid they would only explain the secured party's priority over unsecured consensual claims, not over involuntary claims. Perhaps a simpler rationalization is that consistency requires recognition of the secured creditor's priority. If the secured creditor enjoys priority outside bankruptcy then the debtor's bankruptcy should not affect the secured creditor's position. Unfortunately this explanation also fails to satisfy, since the typical statutory provision establishing the priority of a governmental claim does not distinguish between bankruptcy and non-bankruptcy situations. A further difficulty arises in trying to explain why a deemed trust established by statute in relation to moneys collected by the debtor for the Crown should only be valid if the debtor has in fact kept the moneys in a separate account when no such requirement is imposed in respect to proceeds under section 28 of the Alberta Personal Property Security Act.

I do not wish to leave the impression that there is no answer to these questions and that Parliament should feel free to impose whatever solution is politically expedient or appears equitable. What I hope I have shown is that the traditional explanations for maintaining the secured creditor's priority over governmental claims are not as persuasive as appears at first sight.

\section{Enforcement of the Security Interest}

It goes without saying that both the debtor and its unsecured creditors have a close interest in all aspects of the secured party's enforcement rights. The debtor's interest arises because, if important collateral is seized (and a fortiori if a receiver is appointed over all the assets), the debtor will be out of business. The unsecured creditors are concerned because they share the debtor's anxiety that the secured creditor should not act precipitously and that if a sale of the assets becomes unavoidable the secured party and/or the receiver will make every good faith effort to obtain a fair price for them. Nevertheless, even allowing for the presence of a substantial number of procedural safeguards, ${ }^{71}$ the fact remains that the Part 5 provisions in the Alberta Act are predominantly creditor oriented.

How do we explain this apparent discrepancy? The cynic would say that since Part 5 is based on the Article 9 model it shares the creditor biases of the American drafters and of the rest of Article 9. We may safely assume that secured creditors would energetically reject the suggestion that Part 5 was basically flawed; if anything, they might argue it was too debtor oriented. They would reason, with considerable logic, that there is no point in allowing the taking of security if the security cannot be effectively enforced when the debtor is in default. They would further argue that given the bargain theory of security the debtor and its unsecured creditors must be deemed to have freely accepted Part 5 as an integral part of the security agreement, and that complaining about its defects after the

71. In which should be included the opaque provisions of s. 64, the counterparts of some of which have given the Saskatchewan courts much difficulty. See Re Andrews and Mack Financial (Canada) Ltd. (1988), 46 D.L.R. (4th) 731 (Sask. C.A.), and the author's discussion of the provisions in "The Enforcement of Demand Debentures - Continuing Uncertainties" (publication pending in the Canadian Bar Review). 
event is a natural, but unsustainable, reaction of a debtor which cannot meet its side of the bargain.

This is not the place to debate the question of how much further Part 5 of the Alberta Act could have been relaxed in the debtor's favour without seriously impairing the creditor's bargain. Two examples will illustrate, however, the difficulty of reconciling the bargain theory with recent judicial and statutory developments. The first involves judicial reaction to typical "demand payment" clauses in secured debentures entitling the lender to require repayment of the outstanding loan at any time, whether or not there has been any precipitating act of default, and deeming the debtor to be in default if payment is not made immediately. Such clauses are perfectly consistent with Part 5 of the Alberta Act, as they are with the other Western Provinces' Acts. In fact, the Alberta Act assists such clauses because of its open ended definition of "default", ${ }^{72}$ the debtor's default being the indispensable triggering event entitling the secured creditor to enforce its security agreement pursuant to $\mathbf{s}$. 58 .

As previously noted, starting with the Supreme Court's decision in R.E. Lister Ltd. v. Dunlop Canada ${ }^{73}$ Canadian courts have developed, ${ }^{74}$ more or less from whole cloth, a new judicial doctrine entitling the debtor to a reasonable period of time in which to raise the money demanded by the secured creditor. A recent Ontario Court of Appeal decision has gone even further and has declared unambiguously ${ }^{75}$ that nothing in the parties' agreement can deprive the debtor of this right. Presumably the Alberta courts will invoke the doctrine in construing the meaning of default for the purposes of s. 58(1) of the Alberta Act.

Purists may criticize the courts for ignoring the terms of the parties' own agreement, but it is the critics who are unrealistic. The inescapable inference surely is that the Supreme Court thought it entirely fanciful to suggest that the typical boiler plate demand payment clause reflects the debtor's informed consent. Even if such a foolish debtor could be found, the Advisory Committee was firmly of the view that it would be inimical to the interests of an insolvent debtor's estate if a receiver could be appointed by the secured party without at least giving the debtor adequate notice of its intention to do so. ${ }^{76}$ The Committee went still further and, after considering various alternatives, concluded that every appointment of a receiver should require the approval of the bankruptcy court. $^{n}$

One of the major stumbling blocks in the recasting of the Proposal provisions in Part III of the Bankruptcy Act as part of the revision of the Act has been disagreement about

\footnotetext{
22. Section $1(1)(m)$.

3. [1952] 1 S.C.R. 726.

74. The evolution is traced inter alia in Ziegel, supra, note 70.

75. Kavcar Investments Ltd. v. Aetna Financial Services Ltd. (1989), 62 D.L.R. (4th) 277. See further Ziegel, supra, note 71.

76. Advisory Committee's Report, supra, note 58 at 38 et seq.

n. Ibid. at 39-40, Option A. The Legislative Review Branch, supra, note 58, rejected the recommendation and preferred instead a simple 10 day notice requirement to the debtor before a receiver could be appointed. Ibid. at 5 .
} 
how secured creditors should be dealt with in the revised scheme. All parties agreed that secured creditors should be included in Part III (which they presently are not), that the stay of proceedings after notice of intention to file a proposal had been given should affect enforcement proceedings by secured as well as unsecured creditors, and that for purposes of approving the proposal secured creditors should be treated as a separate class or classes of creditors.

Agreement broke down however about the acceptability of a court formulated proposal ("cram down") where one or more classes of creditors have rejected a debtor formulated proposal. Bill C-60, 1975, the first of the many incarnations of the revised Bankruptcy bills, contained such a provision ${ }^{78}$ and it reappeared in the subsequent bills. Not surprisingly, secured creditors were strongly opposed to any importation of this feature of Chapter 11 of the U.S. Bankruptcy Code, and their objections won the backing of the Bankruptcy Advisory Committee. ${ }^{79}$

We have here a classical confrontation between the bargain theory of secured creditor's rights and communitarian considerations arguing for modification of those rights where it is necessary to save jobs and to rehabilitate an ailing debtor with reasonable prospects of survival in a reorganized form. The confrontation is complicated because the power to veto a proposal enables creditors (secured or unsecured) to engage in opportunistic behaviour with a view to securing a larger share of the pie than they would be likely to receive on a winding up of the company. ${ }^{80}$ Leaving aside this complication, lawyer economists would argue that maintaining this integrity of the creditor bargain is more important than dispensing benevolence, and that if subsidies are necessary (and justifiable) to bail out the debtor they should come from the state and not from the creditor's pocket.

\section{CONCLUSION}

The two Leitmotifs of the provincial personal property security legislation are rationalization and modernization of the complex web of chattel security rules existing under the prior provincial law. The effect of the new legislation is to give Canadian secured creditors one of the most favourable legal environments in the common law world and to encourage creditors to obtain security wherever possible. Unsecured creditors, on the other hand, are the main victims of the enhanced status of secured credit, particularly given the Bankruptcy Act's own benevolent disposition towards security.

The secured creditor's favoured position requires justification. The explanations usually offered, and reviewed in this paper, are based on three main pillars - the historical one (the fact that the personal property security legislation merely consummates a process begun more than a century ago), the bargain theory of security, and the argument that

\section{Section 112.}

79. Supra, note 58 at 53-54. The Legislative Review Branch Proposals do not discuss the issue.

80. Quinn, "Corporate Reorganization and Strategic Behaviour: An Economic Analysis of Canadian Insolvency Law and Recent Proposals for Reform" (1985) 23 Osg. Hall L.J. 1. 
security is efficient and adds more to the community economic welfare that is subtracted from it.

None of these explanations is fully satisfactory. The historical explanation is merely descriptive, and really has no justificatory force; the efficiency argument would be persuasive if economists agreed that security is more than a zero sum game, but they are divided. The bargain theory of security has strong appeal because it is also the basis for the enforcement of bilateral bargain in general although there are important differences between enforcing a bilateral bargain which has no significant impact on the welfare of third parties and one which does.

The bargain theory depends on the existence of fully informed risk neutral unsecured creditors who can readily adjust their credit practices and price structure to offset the higher risk of non-payment or small rate of payment because of the secured creditor's priority. Even if one assumes, probably wrongly, that the bulk of trade creditors fall into this category, it still leaves unprotected a substantial body of vulnerable unsecured creditors - consumers, wage earners, farmers and small trade creditors. While some members of this group can hope to attract special legislative attention, there is some merit in the establishment of a "ten percent" fund as first proposed by the Cork Committee. Governmental non-consensual claims constitute a separate problem in which different values compete for consideration from those obtained in contests between secured and unsecured but consenting creditors.

The various restrictions in the personal property security Acts on the enforcement of the creditor's security unquestionably represent a modification of the creditor's bargain rights. Although mainly procedural in character and designed to ensure good faith conduct in the realization of the collateral, their cumulative effect must affect the value of the collateral itself at least to some extent. This is not to criticize the safeguards, but to indicate that the Acts are not quite as single minded in their pursuit of the secured party's welfare as may appear at first sight. These restrictions on the creditor's realization rights will be further expanded if the Bankruptcy Committee's recommendations on the appointment of private receivers and the inclusion of secured creditors in the revised Part III Bankruptcy Act provisions are enacted into legislative form. The same will be true if the federal government reaffirms its intention to confer on the courts some type of "cram down" powers where secured creditors reject a reorganization proposal.

One lesson that emerges clearly from this discussion is that the new provincial legislation is not self-sufficient. It interacts closely with federal bankruptcy legislation. In the ultimate analysis, secured creditors' rights are only as strong as the recognition afforded them by federal law. 
The various restrictions in the personal property security Acts on the enforcement of the creditor's security unquestionably represent a modification of the creditor's bargain rights. Although mainly procedural in character and designed to ensure good faith conduct in the realization of the collateral, their cumulative effect must affect the value of the collateral itself at least to some extent. This is not to criticize the safeguards, but to indicate that the Acts are not quite as single as single minded in their pursuit of the secured party's welfare as may appear at first sight. These restrictions on the creditor's realization rights will be further expanded if the Bankruptcy Committee's recommendations on the appointment of private receivers and the inclusion of secured creditors in the revised Part III Bankruptcy Act provisions are enacted into legislative form. The same will be true if the federal government reaffirms its intention to confer on the courts some type of "cram down" powers where secured creditors reject a reorganization proposal.

One lesson that emerges clearly from this discussion is that the new provincial legiislation is not self-sufficient. It interacts closely with federal bankruptcy legislation. In the ultimate analysis, secured creditors' rights are only as strong as the recognition affored them by federal law. 